Katarzyna Żukrowska*

\title{
PROBLEM SYMETRII MIĘDZY OTWARTĄ GOSPODARKĄ A OTWARTYM SPOŁECZEŃSTWEM
}

Jedną z przyczyn zahamowania procesu reform, krytycznego nastawienia do globalizacji i związanej z nią liberalizacji jest brak symetrii między otwarciem gospodarek a otwarciem społeczeństw. W artykule analizuje się ten problem, zaczynając od definicji obu pojęć, przedstawienia mierników otwarcia gospodarki i społeczeństwa oraz pokazania stanu asymetrii czy nierównowagi między nimi. Opracowanie składa się z wstępu, czterech części merytorycznych i zakończenia. W pierwszej części omówiono występujące tu pojęcia, zastosowane mierniki, warunki stymulujące i hamujące procesy otwierania w obu przypadkach. W części drugiej przedstawiono kwestie związane $\mathrm{z}$ równowagą między otwarciem gospodarki a otwarciem społeczeństwa; w trzeciej - problem braku równowagi czy symetrii między dwoma omawianymi procesami i możliwe konsekwencje tego zjawiska. W części czwartej skoncentrowano się na kwestiach równowagi między dwoma zjawiskami: otwarciem gospodarki i społeczeństwa oraz warunkami równowagi.

\section{Pojęcia i ich definicje oraz mierniki}

W tej części artykułu przedstawiono definicje pojęć „otwarta gospodarka” $i$ „otwarte społeczeństwo", pokazano, kiedy tych pojęć zaczęto używać i w jakim kontekście oraz co było tego przyczyną. Zaprezentowano również zastosowane tu mierniki.

\subsection{Otwarta gospodarka}

Gospodarkę uważa się za otwartą, kiedy działalność gospodarcza na danym rynku jest silnie powiązana $\mathrm{z}$ działalnością prowadzoną na zewnątrz tego rynku

* Kolegium Ekonomiczno-Społeczne, Szkoła Główna Handlowa w Warszawie. 
- czy to narodowego, czy regionalnego. Wszystkie podmioty gospodarcze: osoby prawne i osoby fizyczne mogą angażować się w handel dobrami, usługami, a także przeprowadzać bez przeszkód i ograniczeń związane z takimi działaniami transakcje finansowe. Oznacza to angażowanie osób prawnych i fizycznych z wielu rynków, warunkiem jest możliwość swobodnej komunikacji, możliwość przeprowadzenia koniecznych transferów bez większych przeszkód handlowych (taryfy, bariery pozataryfowe, parataryfowe), odpowiednia infrastruktura fizyczna, prawna, instytucjonalna. Należy tu podkreślić, że przy tak ogólnej definicji mamy pewne dziedziny, w których z innych względów niż ochrona (protekcja czy zamknięcie rynku) takich międzynarodowych ruchów nie będzie się odnotowywało. Dotyczy to np. braku możliwości transferu międzynarodowego nieruchomości czy wielu usług, które mogą być świadczone wyłącznie w miejscach ich świadczenia, co wymaga odpowiednio wyposażonej infrastruktury (usługa przewozu transportem kolejowym czy miejska tramwajem).

Przeciwstawiając pojęciu otwartej gospodarki pojęcie zamkniętej gospodarki, należy powiedzieć, że w przypadku tej drugiej stosowane bariery taryfowe, instytucjonalne, prawne i pozostałe rozwiązania prowadzące do protekcji uniemożliwiają międzynarodowy handel lub przeprowadzanie międzynarodowych transakcji finansowych ${ }^{1}$. W gospodarce zamkniętej całkowity dochód $(Y)$ to suma konsumpcji $(C)$, inwestycji $(I)$ oraz wydatków państwa $(G)$. W gospodarce otwartej część produkcji jest sprzedawana i konsumowana za granicą. Podobnie jest $\mathrm{z}$ inwestycjami, część $\mathrm{z}$ nich jest angażowana na rynkach zagranicznych. Podobna uwaga dotyczy wydatków państwa, jeśli państwo angażuje się np. w pomoc innym państwom. Tym samym nasz prosty wzór przyjmie nową, rozszerzoną formę. Całkowity dochód $(Y)$ to suma konsumpcji krajowej $(C d)$, inwestycji krajowych $(I d)$ oraz krajowych wydatków państwa $(G d)$, a także eksportu towarów, usług oraz kapitału $(X)$. Ponieważ otwarcie gospodarki nie jest ograniczone do eksportu, ale obejmuje również i import (Im), to import będzie stanowił dodatkowy czynnik wpływający na dochód danego państwa i obejmuje te same elementy składowe, które wymienia się po stronie eksportu. Tym samym nasza formuła przyjmie postać następującą:

$$
Y=C d+I d+G d+X-I m
$$

Ponieważ wartość importu (Im) stanowi część wydatków na rynku danego kraju, nie będąc jednak produkcją wykonaną na danym rynku, można tę wartość odjąć od

1 A. Clark, Economics Through Everyday Life. From China and Chili Dogs to Marx and Marijuana, Zephyros Press, Berkley 2016. 
wartości produkcji wytwarzanej na danym rynku. Tym samym eksport netto $(X n)$ to wartość eksportu $(X)$ po odjęciu całkowitej wartości importu (Im). Uzupełnienie to prowadzi do pewnych zmian przyjętego wcześniej modelu i przyjmuje następującą postać:

$$
Y=C+I+G+X n
$$

W modelu zamkniętym gospodarki inwestycje (I) równają się oszczędnościom $(S)$. W modelu otwartym sytuacja przedstawia się inaczej. Wychodząc od wzoru [2], gdzie całkowity dochód $(Y)$ to suma konsumpcji $(C)$, inwestycji (I), wydatków państwa $(G)$ oraz wartość eksportu netto $(X n)$, należy z obu stron równania odjąć konsumpcję i wydatki państwa. Wzór przyjmie następującą postać:

$$
Y-C-G=I+X n
$$

gdzie narodowe oszczędności $(Y-C-G)$ równają się sumie prywatnych oszczędności $(Y-T-C)$ i publicznych oszczędności $(T-G)$, gdzie dochody państwa z podatków oznaczone są symbolem $(T)$. Oznacza to, że oszczędności $(S)$ to inwestycje $(I)$ powiększone o eksport netto $(X n)$, co przybiera taką postać:

$$
S=I+X n
$$

Po odjęciu z obu stron równania inwestycji nasz wzór przybiera następującą formę:

$$
S-I=X n
$$

Wyniki rachunku narodowego w postaci bieżącego rachunku handlowego bilansu płatniczego wskazują, że to, czy kraj jest eksporterem, czy importerem kapitału jest konsekwencją wyniku jego bilansu handlowego. Jeżeli oszczędności po odjęciu inwestycji dają wynik dodatni, to na rachunku bieżącym obserwujemy nadwyżkę. Oznacza to, że eksport jest wyższy od importu, a więc dane państwo kwalifikuje się jako pożyczkodawca na rynku kapitałowym. Jeżeli obserwujemy sytuację odwrotną, tzn. jeśli import jest wyższy od eksportu, dane państwo staje się kredytobiorcą na rynku kapitałowym².

2 R. Dornbush, S. Fisher, R. Starz, Macroeconomics, McGraw-Hill Book Comp. 2001, $8^{\text {ht }}$ ed. (DFS), http:// highered.mcgraw-hill.com/sites/0072823402/information_center_view0/; N.G. Mankiw, Macroeconomics, $4^{\text {th }}$ ed., Worth 1999, http://bcs.worthpublishers.com/mankiw6/ 
Gospodarka otwarta zaangażowana jest w handel międzynarodowy, który jest pochodną międzynarodowego podziału pracy, a jego obecna postać formowała się przez wieki, rozpoczynając od podziału ukształtowanego, przez warunki naturalne klimatyczne, geologiczne, geograficzne czy ludnościowe, na osiągniętym przez dany rynek poziomie rozwoju kończąc ${ }^{3}$. Ten drugi warunek (poziom rozwoju) uzależniony był od stanu edukacji społeczeństwa, pracowitości, zaangażowania itp.

Handel międzynarodowy początkowo obejmował transfer surowców, produktów rolnych i ich pochodne (pszenicę, mąkę, herbatę, kawę, len, wełnę), po czym zaczął włączać również produkty przetworzone (sukno, jedwab, proch, dzieła sztuki) ${ }^{4}$. Taki międzynarodowy podział pracy można było określać jako międzygałęziowy. Z czasem, wraz z rozwojem komunikacji i otwieraniem się gospodarek, handel międzygałęziowy został zastąpiony handlem wewnątrzgałęziowym ${ }^{5}$. Oznaczało to przenoszenie części faz produkcji na rynki, które zapewniały obniżenie kosztów produkcji i podnosiły cenową konkurencyjność. Kolejna faza międzynarodowego podziału pracy objęła podział na produkcję fizyczną (wytwarzanie produktów przemysłowych) i produkcję własności intelektualnej (technologia, organizacja, reklama, marketing itp.) ${ }^{6}$. Sekwencyjna ewolucja międzynarodowego podziału pracy oparta jest na kilku procesach:

- liberalizacji wymiany handlowej i przepływu BIZ, regulacja dotyczy własności intelektualnej ${ }^{\top}$;

- odejściu od standardu opartego na złocie i zastąpieniu go przez płynny kurs;

- powszechności członkostwa w takich organizacjach jak MFW $\left(189^{8}\right), \mathrm{BS}\left(189^{9}\right)$ i WTO (164 państwa członkowskie ${ }^{10}$ i 23 obserwatorów ${ }^{11}$ );

- regionalizacji i przenoszeniu się rozwiązań poza narodowe rynki;

- rozwoju sekwencyjnym poszczególnych regionów, czy nawet szerzej kontynentów (Europa Zachodnia ${ }^{12}$, Ameryka Północna, Japonia, potem Europa Wschod-

\footnotetext{
3 J.C. Nash, M.P. Fernandez-Kelly, Women, Men, and the International Division of Labor, Sunny Press, New York 1983, s. 39.

4 P. Krugman, R. Wells, Macroeconomics, $4^{\text {th }}$ ed., Worth Publ., New York 2015, s. 541.

5 K. Raworth, Doughnut Economics. 7 ways to think like a 21st Century Economist, Chelsea Green Publ., Vermont 2017, s. 53-81.

6 Ibidem, s. 111-139.

7 R.D. Atkinson, S.J. Ezeell, Innovation Economics. The Race for Global Advantage, Yale University Press, New Haven-London 2012, s. 162.

8 https://www.imf.org/external/np/sec/memdir/memdate.htm [dostęp 12.09.2017].

9 http://www.worldbank.org/en/about/leadership/members [dostęp 12.09.2017].

10 https://www.wto.org/english/thewto_e/whatis_e/tif_e/org6_e.htm [dostęp 12.09.2017].

11 https://www.wto.org/english/thewto_e/whatis_e/tif_e/org6_e.htm\#observer [dostęp 12.09.2017].

12 K. Żukrowska, Rozwój Unii Europejskiej do 2020 roku a nowe wyzwania globalizacji $i$ konkurencji międzynarodowej z uwzględnieniem roli, miejsca i interesów Polski, „Krakowskie Studia Międzynarodowe” nr 1(XVII), 2017, s. 17-34.
} 
nia, Azja Pacyfiku, następnie reszta świata: Chiny, Indie, Ameryka Południowa, RPA, Afryka Północna);

- rozwoju infrastruktury komunikacyjnej i cyfryzacji;

- obniżeniu kosztów transportu;

- sekwencyjności członkostwa w organizacjach globalnych ${ }^{13}$ i sekwencyjności rozwoju ${ }^{14}$.

Stopniowe zmiany zachodzące $\mathrm{w}$ regionach czy na kontynentach powodowały sytuację, w której państwa bardziej rozwinięte miały interes w bliższej współpracy z gospodarkami reprezentującymi niższy poziom rozwoju ${ }^{15}$. Podobna opinia może być wyrażona o gospodarkach reprezentujących niższy i całkiem niski poziom rozwoju (w literaturze, a także nomenklaturze ONZ występuje określenie least developer economies - LDC) ${ }^{16}$. Interesy te przestają być sprzeczne i konfliktowe, ponieważ poszczególne gospodarki reprezentują różny poziom rozwoju. Widoczny sukces części państw, które otworzyły swoje gospodarki (Singapur, Australia, Nowa Zelandia, Chiny), czemu towarzyszyły nadwyżki na rachunku bieżącym bilansu płatniczego, stanowił dla części gospodarek dowód powodzenia stosowanej strategii otwarcia i stał się wzorem do naśladowania. Nie oznaczało to jednak powszechnej akceptacji takiego modelu, który w praktyce powinien był wypychać koncepcje stosowane w polityce industrializacji stosowane w latach 1960-1970 (Japonia, potem Korea Płd.).

Mierniki otwarcia gospodarki są zróżnicowane i obejmują proste równania lub bardziej skomplikowane i złożone sposoby pomiaru.

Tabela 1. Mierniki otwarcia gospodarki

\begin{tabular}{|c|l|l|l|}
\hline Lp. & \multicolumn{1}{|c|}{ Model } & \multicolumn{1}{|c|}{ Skuteczność } & \multicolumn{1}{|c|}{ Ocena } \\
\hline 1 & Pokrycie importu eksportem $(E / l)$ & $\begin{array}{l}\text { Małe gospodarki wykazują większą } \\
\text { otwartość od dużych }\end{array}$ & $\begin{array}{l}\text { Wskaźnik stosowany, choć } \\
\text { z zastrzeżeniami }\end{array}$ \\
\hline 2 & $\begin{array}{l}\text { Udział obrotów handlu } \\
\text { zagranicznego w PKB }(Y)\end{array}$ & $\begin{array}{l}\text { Podobna uwaga jak wyżej } \\
\text { budzaźnik zastrzę̇eżenia }\end{array}$ \\
\hline 3 & $\begin{array}{l}\text { Wskaźnik obrotów handlu } \\
\text { zagranicznego na głowę ludności }\end{array}$ & $\begin{array}{l}\text { Państwa o dużych populacjach } \\
\text { będą wskazywały na relatywne } \\
\text { zamknięcie gospodarki }\end{array}$ & $\begin{array}{l}\text { Wskaźnik stosowany - budzi } \\
\text { zastrzeżenia }\end{array}$ \\
\hline
\end{tabular}

${ }^{13}$ K. Żukrowska, Ocena interesów gospodarczych i politycznych w układzie Świat Zachodni - Azja, [w:] Kryzysy systemowe. Zagrożenia globalne barierami rozwoju, red. nauk. E. Mączyńska, J.J. Michalak, J. Niżnik, PAN, Komitet Prognoz Polska 2000+, Warszawa 2013, s. 279-293.

14 K. Żukrowska, Powiązania liberalizacyjne rynków z różnych regionów/Liberalizationties of markets fromdifferent region, „Ekonomia XXI wieku/Economics of the $21^{\text {st }}$ Century” UE we Wrocławiu 3(11), 2016, s. 11-25.

15 P. Krugman, R. Wells, op.cit., s. 563 i n.

16 R. O’ Brien, M. Williams, Global Political Economy, $3^{\text {rd }}$ ed., Palgrave-Macmillan, London 2010, s. 424. 


\begin{tabular}{|c|l|l|l|}
\hline Lp. & \multicolumn{1}{|c|}{ Model } & \multicolumn{1}{|c|}{ Skuteczność } & \multicolumn{1}{|c|}{ Ocena } \\
\hline 4 & $\begin{array}{l}\text { Wielkość wyniku rachunku } \\
\text { bieżącego do PKB }\end{array}$ & $\begin{array}{l}\text { Państwa surowcowe w okresach } \\
\text { wzrostu cen mogą uzyskiwać } \\
\text { wyniki odbiegające od } \\
\text { rzeczywistego obrazu ich sytuacji }\end{array}$ & $\begin{array}{l}\text { Wskaźnik stosowany - budzi } \\
\text { zastrzeżenia }\end{array}$ \\
\hline 5 & $\begin{array}{l}\text { Wielkość wyniku bilansu } \\
\text { płatniczego do PKB }\end{array}$ & $\begin{array}{l}\text { Państwa surowcowe oraz } \\
\text { duzi producenci przemystowi } \\
\text { w okresach wzrostu cen mogą } \\
\text { uzyskiwać wyniki odbiegające od } \\
\text { rzeczywistego obrazu ich sytuacji }\end{array}$ & $\begin{array}{l}\text { Wskaźnik stosowany - budzi } \\
\text { zastrzeżenia }\end{array}$ \\
\hline 6 & $\begin{array}{l}\text { Wskaźnik obrotów handlu } \\
\text { zagranicznego w stosunku } \\
\text { do produkcji przemystowej }\end{array}$ & $\begin{array}{l}\text { Wskaźnik uwzględnia zmiany } \\
\text { strukturalne gospodarki światowej }\end{array}$ & $\begin{array}{l}\text { Stosowany przez ONZ } \\
\text { - odzwierciedla stan zmian } \\
\text { strukturalnych gospodarki } \\
\text { światowej }\end{array}$ \\
\hline
\end{tabular}

Źródło: Zestawienie własne.

Otwarcie gospodarki można mierzyć za pomocą prostych wskaźników, tradycyjnie stosowanych, które na ogół sprowadza się do stopy importu lub eksportu wyliczanej na podstawie udziału wartości importu lub eksportu w stosunku do PKB. Można również stosować kilka różnych, dodatkowych mierników, które obejmują tradycyjne bariery taryfowe, a także bariery pozataryfowe i parataryfowe. Takim uniwersalnym i dość rozbudowanym wskaźnikiem jest ocena otwarcia gospodarki przygotowywana przez Heritage Foundation (HF). Wskaźnik znany jest jako Economic Freedom Index i wyliczany jest przez HF co roku, czyli przedstawia aktualizowane dane ${ }^{17}$. Bada się tu 180 państw pod kątem czterech zasadniczych cech wskazujących na stan swobody gospodarczej. Są to:

- przepisy prawne i ich przestrzeganie,

- wielkość rządu,

- efektywność regulacji prawnych,

- otwartość rynków.

W ramach tych czterech bloków sprawdza się dodatkowo po trzy dodatkowe charakterystyki. Zostało to pokazane na przykładzie Polski z raportu Economic Freedom z 2017 r.

Polska plasuje się na 45 miejscu na 180 badanych państw. Ocena punktowa Polski to 68,3 pkt., co oznacza, że kraj nasz jest zaliczany do gospodarek o umiarkowanych swobodach gospodarczych. Gospodarki w tej grupie mieszczą się ze swoimi ocenami między 60,00 a 69,9 pkt. Najbardziej wolne gospodarczo rynki mieszczą się ze swoimi ocenami w grupie 80-100 pkt. Rynki o bardzo niskim poziomie swobód zawierają się w punktacji 50,0-59,9.

17 http://www.heritage.org/index/ [dostęp 2.02.2018]. 
Tabela 2. Economic Freedom Index (Indeks swobód gospodarczych) według Heritage Foundation dla 2017 r. Przykład Polski

\begin{tabular}{|l|l|c|l|}
\hline \multicolumn{1}{|c|}{ Dziedzina } & \multicolumn{1}{|c|}{ Szczegółowe mierniki } & Ocena ogólna & Zmiana w stosunku do 2016 r. \\
\hline \multirow{3}{*}{$\begin{array}{l}\text { Przepisy prawne i ich } \\
\text { przestrzeganie }\end{array}$} & prawa własności & 60,8 & spadek \\
\cline { 2 - 4 } & spójność działania rządu & 55,5 & spadek \\
\cline { 2 - 4 } & sprawność sądownictwa & 58,0 & brak zmian \\
\hline \multirow{4}{*}{ Wielkość rządu } & wydatki rządowe & 46,9 & poprawa \\
\cline { 2 - 4 } & obciążenia podatkowe & 76,0 & poprawa \\
\cline { 2 - 4 } & polityka fiskalna & 76,1 & bez zmian \\
\hline \multirow{3}{*}{$\begin{array}{l}\text { Efektywność regulacji } \\
\text { prawnych }\end{array}$} & wolność prowadzenia biznesu & 67,8 & spadek \\
\cline { 2 - 4 } & wolność na rynku pracy & 61,5 & poprawa \\
\cline { 2 - 4 } & swoboda polityki monetarnej & 84,7 & spadek \\
\hline \multirow{3}{*}{ Otwartość rynków } & swoboda polityki handlowej & 87,0 & spadek \\
\cline { 2 - 4 } & swoboda polityki inwestycyjnej & 75,0 & bez zmian \\
\cline { 2 - 4 } & swoboda finansowa & 70,0 & bez zmian \\
\hline
\end{tabular}

Źródło: http://www.heritage.org/index/country/poland [dostęp 2.02.2018].

Tabela 3. Rankingi międzynarodowe wybranych państw według Indeksu swobód gospodarczych (10 najbardziej otwartych gospodarek, USA i państwa UE) w 2017 r.

\begin{tabular}{|c|c|c|c|c|c|c|c|c|c|}
\hline \multicolumn{10}{|c|}{ Gospodarki oceniane jako najbardziej wolne gospodarczo (80-100 pkt.) } \\
\hline Ranking & Kraj & $\begin{array}{l}\text { Liczba } \\
\text { pkt. }\end{array}$ & $\underset{\%}{\operatorname{Zmiana}}$ & $\begin{array}{l}\text { Kierunek } \\
\text { zmiany }\end{array}$ & Ranking & Kraj & $\begin{array}{c}\text { Liczba } \\
\text { pkt. }\end{array}$ & $\underset{\%}{\operatorname{Zmiana}}$ & $\begin{array}{l}\text { Kierunek } \\
\text { zmiany }\end{array}$ \\
\hline 1 & Hongkong & 89,9 & 1,2 & poprawa & 2 & Singapur & 88,6 & 0,8 & poprawa \\
\hline 3 & Nowa Zelandia & 83,7 & 2,1 & poprawa & 4 & Szwajcaria & 81,5 & 0,5 & poprawa \\
\hline 5 & Australia & 81,0 & 0,7 & poprawa & & & & & \\
\hline \multicolumn{10}{|c|}{ Gospodarki oceniane jako prawie wolne $(70,0-79,9)$} \\
\hline 6 & Estonia & 79,1 & 1,9 & poprawa & 7 & Kanada & 78,5 & 0,5 & poprawa \\
\hline 8 & $\begin{array}{l}\text { Zjednoczone } \\
\text { Emiraty Arabskie }\end{array}$ & 76,9 & 4,3 & poprawa & 9 & Irlandia & 76,7 & $-0,6$ & spadek \\
\hline 10 & Chile & 76,5 & $-1,2$ & spadek & 12 & Wielka Brytania & 76,4 & 0,0 & bez zmian \\
\hline 14 & Luksemburg & 75,9 & 2,0 & poprawa & 15 & Holandia & 75,9 & 2,0 & poprawa \\
\hline 16 & Litwa & 75,8 & 0,6 & poprawa & 17 & USA & 75,1 & $-0,3$ & spadek \\
\hline 18 & Dania & 75,1 & $-0,2$ & spadek & 19 & Szwecja & 74,9 & 2,9 & poprawa \\
\hline 20 & Łotwa & 74,8 & 4,4 & poprawa & 24 & Finlandia & 74,0 & 1,4 & poprawa \\
\hline 26 & Niemcy & 73,8 & $-0,6$ & spadek & 28 & Czechy & 73,3 & 0,1 & poprawa \\
\hline 30 & Austria & 72,3 & 0,6 & poprawa & & & & & \\
\hline \multicolumn{10}{|c|}{ Gospodarki oceniane jako umiarkowanie wolne $(60,0-69,9)$} \\
\hline 39 & Rumunia & 69,7 & 4,1 & poprawa & 45 & Polska & 68,3 & $-1,0$ & spadek \\
\hline 47 & Bułgaria & 67,9 & 2,0 & poprawa & 48 & Cypr & 67,9 & $-0,8$ & spadek \\
\hline
\end{tabular}




\begin{tabular}{|c|c|c|c|c|c|c|c|c|c|}
\hline \multicolumn{10}{|c|}{ Gospodarki oceniane jako najbardziej wolne gospodarczo (80-100 pkt.) } \\
\hline Ranking & Kraj & $\begin{array}{c}\text { Liczba } \\
\text { pkt. }\end{array}$ & $\underset{\%}{Z}$ & $\begin{array}{c}\text { Kierunek } \\
\text { zmiany }\end{array}$ & Ranking & Kraj & $\begin{array}{c}\text { Liczba } \\
\text { pkt. }\end{array}$ & $\underset{\%}{Z \text { Zmiana }}$ & $\begin{array}{l}\text { Kierunek } \\
\text { zmiany }\end{array}$ \\
\hline 49 & Belgia & 67,8 & $-0,6$ & spadek & 50 & Malta & 67,7 & 1,0 & poprawa \\
\hline 56 & Węgry & 65,8 & $-0,2$ & spadek & 57 & Stowacja & 65,7 & $-0,9$ & spadek \\
\hline 69 & Hiszpania & 63,6 & $-4,9$ & spadek & 72 & Francja & 63,3 & 1,0 & poprawa \\
\hline 77 & Portugalia & 62,6 & $-2,5$ & spadek & 79 & Włochy & 62,5 & 1,3 & poprawa \\
\hline \multicolumn{10}{|c|}{ Gospodarki oceniane jako prawie całkowicie pozbawione swobód gospodarczych $(9,0-59,9)$} \\
\hline 95 & Chorwacja & 59,4 & 0,3 & poprawa & 97 & Stowenia & 59,2 & $-1,4$ & spadek \\
\hline 127 & Grecja & 55,0 & 1,8 & poprawa & & & & & \\
\hline \multicolumn{10}{|c|}{ Gospodarki nieanalizowane w rankingach } \\
\hline 1 & Liechtenstein & & & & 2 & Irak & & & \\
\hline 3 & Libia & & & & 4 & Somalia & & & \\
\hline 5 & Syria & & & & 6 & Jemen & & & \\
\hline
\end{tabular}

Źródło: http://www.heritage.org/index/ranking [dostęp 2.02.2018].

Interesujące mogą być wnioski wskazujące, że najbardziej otwarte gospodarki to rynki azjatyckie, czy szerzej Azji-Pacyfiku: Hongkong i Singapur, Nowa Zelandia i Australia oraz w Europie - Szwajcaria. Wśród państw członkowskich UE najbardziej otwartą gospodarkę mają Estonia i Irlandia, a następnie Wielka Brytania, Luksemburg i Holandia. Warto zwrócić uwagę na ten fakt ze względu na wspólną politykę handlową, gdyż zróżnicowanie otwarcia państw członkowskich UE oznacza, że poza polityką handlową realizowaną przez UE państwa członkowskie mogą samodzielnie dokonywać pewnych posunięć w ramach swej polityki gospodarczej, które służą albo otwieraniu ich gospodarek, albo protekcji. W grupie rynków, które z gospodarek planowych stały się rynkowymi i dołączyły w 2004 r. do UE, wyróżnia się rynek wspomnianej wcześnie Estonii, Litwy, Łotwy i Czech. Polski rynek plasuje się $\mathrm{w}$ tym rankingu $\mathrm{w}$ grupie gospodarek umiarkowanie wolnych między gospodarką Rumunii i Bułgarii, które dołączyły do UE w 2007 r. Znając szczegółową historię pierwszej dekady transformacji w Polsce, można powiedzieć, że proces ten uległ wyraźnemu załamaniu po etapie bardzo szybkiego otwierania rynku ${ }^{18}$. Oczywiście, że szukając argumentów podpierających koncepcję powolnego otwierania gospodarki, można wskazać na Francję czy Grecję i kilka jeszcze innych rynków, które wypadają w tym rankingu gorzej od polskiego. Nie chodzi jednak o argumenty wspierające decyzje o spowolnieniu procesów liberalizacji, ale pokazanie, że spowolnienie procesu otwierania jest jednoznaczne z powolniejszym rozwojem, a co za tym idzie spowolnieniem procesu pomnażania dobrobytu, a więc podnoszenia stopy życiowej

18 Transformacja systemowa w Polsce, red. K. Żukrowska, Oficyna Wydawnicza SGH, Warszawa 2010. 
ludności i pokonywania luki rozwoju. Przykładem pozytywnym dla Polski w tym przypadku powinna być Wielka Brytania, która wśród tzw. starych państw członkowskich UE (choć dołączyła do byłej EWG w 1973 r. i nie uczestniczyła od początku $\mathrm{w}$ tworzeniu Unii, stymulując procesy integracji $\mathrm{w}$ ramach EFTA) ma jedną $\mathrm{z}$ bardziej otwartych gospodarek.

Otwarcie gospodarki ma tym większe znaczenie, że środki, instrumenty taryfowe protekcji, są na ogół redukowane szybciej i skuteczniej, jednak na ich miejsce państwa wprowadzają rozwiązania parataryfowe lub pozataryfowe. Ich rola jest duża w przypadku ochrony rynków w dziedzinach, które odgrywają zasadniczą rolę w rozwoju, tworzeniu miejsc pracy, zapewnianiu warunków dla kształtowania dobrobytu ${ }^{19}$. Chodzi tu o dobra innowacyjne, a zwłaszcza o technologie informacyjno-komunikacyjne ${ }^{20}$. Zasadniczo obserwuje się pewną prawidłowość w gospodarce świata: rynki bardziej zaawansowane mają lepiej rozwiniętą sieć protekcji pozataryfowej i parataryfowej, a rynki gospodarek reprezentujących niższy poziom rozwoju koncentrują się w swej polityce protekcji na stosowaniu instrumentów taryfowych.

W tym kontekście warto zwrócić uwagę na fakt, że stan otwarcia gospodarki wyprzedza szereg innych procesów w niej zachodzących. Przykładem jest szybsze otwarcie gospodarki w stosunku do zmian stosowanej w niej polityki gospodarczej, która często zawiera pewne elementy działań typowe dla działań podejmowanych w gospodarce zamkniętej. (Przykład: działania interwencyjne kanclerz A. Merkel podczas kryzysu 2008 r., sprowadzające się do obniżenia podatku od nowych zakupionych aut niemieckich marek. Działanie to wyszło poza granice rynku niemieckiego i objęło polskich producentów niemieckich marek). Innym przykładem są hasła „kupuj ... krajowe/narodowe” w warunkach, w których większość produktów ma komponenty (czasami przewagę komponentów) wytwarzane i importowane z zagranicy. Oznacza to, że często hasła polityków trafiają do konsumentów, ale dzieje się to $\mathrm{w}$ wyniku braku ich wiedzy, a nie w efekcie rzeczywistych zmian na rynku czy konsekwencji tych zmian, które są nie tylko trudne, ale najczęściej wręcz niemożliwe do przeprowadzenia. Oznaczałyby bowiem skokowy wzrost cen dla konsumentów i w konsekwencji ich relatywnie zubożenie, przy założeniu utrzymania innych warunków (takich jak płace na dotychczasowym poziomie; zmiana płac mogłaby przywrócić nawrót presji inflacyjnej, co również oznaczałoby relatywne spadki siły nabywczej poszczególnych walut i podobny efekt - relatywnego ubożenia ${ }^{21}$.

19 R.D. Atkinson, S.J. Ezeell, op.cit., s. 162.

20 K. Żukrowska, Światowy rynek ICT szansa czy zagrożeniem dla miejsc pracy? [maszynopis 2018, tekst w druku].

21 As GM Falters, Opel Seeks Government Help, 17.11.2008, Spiegel Online (http://www.spiegel.de/international/germany/auto-industry-bailout-as-gm-falters-opel-seeks-government-help-a-590906.html [dostęp 25.06.2018]. 
W tym kontekście warto spojrzeć również na problem otwarcia społeczeństwa czy inaczej braku otwartego społeczeństwa w krajach UE. Otwarte społeczeństwo może być uzupełnieniem, żeby nie nazwać tego warunkiem koniecznym kontynuacji procesu otwierania gospodarki ${ }^{22}$. Twierdzenie to opiera się na założeniu, że ekonomia jest polityczna, a braki edukacyjne o świecie, zmianach w nim zachodzących mogą służyć nie tylko do manipulowania wyborcami, ale przede wszystkim do hamowania procesów rozpoczętych po 1989 r. Twierdzenie to nie ogranicza się wyłącznie do państw, które przeszły głębokie zmiany systemowe, ale też państw i społeczeństw, które są rynkowymi demokracjami od okresu powojennego czy weszły na tę drogę później, ale dużo przed 1989 r. Chodzi tu o państwa, które dołączyły do Wspólnot Europejskich w latach 1970-1980.

\subsection{Otwarte społeczeństwo}

Otwarte społeczeństwo to pojęcie nie najnowsze. Po raz pierwszy w literaturze sformułowane zostało przez francuskiego filozofa Henriego Bergsona w latach 30. $\mathrm{XX} \mathrm{w}^{23}$ Jego opracowania z perspektywy czasu są oceniane różnie, jednak elementem wspólnym w tych ocenach jest twierdzenie, że koncepcje filozoficzne przyniosły ich autorowi literacką Nagrodę Nobla (1927 r.), a swoją koncepcję otwartego społeczeństwa pisał w warunkach budzenia się nacjonalizmów, populizmu i wreszcie faszyzmu w państwach europejskich. Koncepcja otwartego społeczeństwa Bergsona została rozwinięta w latach 40. XX w. przez Karla Poppera, filozofa brytyjskiego z austriackimi korzeniami. Na ogół też Popper jest uznawany za twórcę tego pojęcia i związanej z nim koncepcji ${ }^{24}$. Bergson wskazuje, że warunkiem rodzenia się zamkniętych społeczeństw są szczelne systemy państwowe uformowane przez przepisy prawne i wąską interpretację kanonów wprowadzonych przez dominującą religię. Przeciwieństwem zamkniętego społeczeństwa jest otwarte społeczeństwo, które rozwija się dynamicznie, czego nieodłącznym elementem jest tolerancja, akceptacja odrębności, inności i uniwersalizm moralny. W otwartych społeczeństwach system polityczny, zasady działania administracji są przejrzyste, jawne i elastyczne. Rozwiązania takie nie powinny być utożsamiane $\mathrm{z}$ odrzuceniem przeszłości czy tradycji, oznaczają bowiem ewolucyjne zmiany, w których uwzględnia się adaptację do nowych

22 R.J. Holton, Globalization and the Nation State, $2^{\text {nd }}$ ed., Palgrave-Macmillan, London-New York 2011, s. $127 \mathrm{i} \mathrm{n.}$

23 H. Bergson, The Two Sources of Morality and Religion (tłum. z franc. R. Ashley Andra, C. Brereton), Doubleday Anchor 1935, s. 18-27, 45-65, 229-234); tytuł oryg.: Les deux sources de la morale et de la religion (1932), rozdz. I, s. 1-103, oraz IV, s. 287-343.

24 K.R. Popper, The Open Society and its Enemies, Routledge, London 1995, s. 185-218. 
warunków funkcjonowania państw i ich gospodarek, w czym bierze się pod uwagę zarówno nowe technologie, jak i nowatorskie rozwiązania instytucjonalno-prawne w skali międzynarodowej umożliwiające większą współpracę międzynarodową, przyspieszenie rozwoju, obniżenie jego kosztów w porównaniu z działaniami indywidualnymi każdego z państw z osobna. Oznacza to harmonizację prawa i rozwiązań instytucjonalnych w państwach współpracujących ze sobą. Taki system międzynarodowy powstał po doświadczeniach II wojny światowej, czyli w efekcie stworzenia systemu z BrettonWoods, którego trzonem stała się ONZ i jej agencje: MFW, BŚ i GATT/WTO.

Warunki stworzone przez zasady dominującej kultury, czego ważnym elementem jest religia, i obowiązujące prawodawstwo są nie tylko statyczne, a więc nie stymulują reakcji na zmiany zachodzące w otoczeniu, ale dodatkowo wpływają ograniczająco na postrzeganie tych zmian. Często zjawisko takie utożsamiane jest $\mathrm{z}$ „zamkniętym umysłem", jednak pojęcie to bardziej odnieść można do jednostki niż do całego społeczeństwa. To ostatnie zjawisko osadzone jest w naturze ludzkiej, gdzie tylko część społeczeństwa jest nastawiona na poznanie i odkrycia, część akceptuje odkrycia i nowości, a pozostali obywatele odrzucają nowości i wybierają to, co znali w przeszłości.

W polityce zamknięte społeczeństwa tworzą struktury administracyjne oparte na przekonaniu, że rządzący mają najlepszą wiedzę, jak sprawować władzę i jak kierować polityką oraz państwem. Systemy zamkniętych społeczeństw to monarchia, feudalizm, a także rządy autorytarne. Rozwiązaniom autorytarnym, ich utrzymaniu i wzmocnieniu służą rozwiązania prawne i instytucjonalne. Podważenie takiej władzy wymaga głębokich zmian prawnych i instytucjonalnych. Reformom w kierunku demokratyzacji i osłabieniu totalitarnych rozwiązań sprzyja członkostwo w organizacjach międzynarodowych takich jak ONZ, MFW, BŚ czy OECD i UE. W sferze finansów dodatkowo wpływ na stosowane przez państwa rozwiązania mają zalecenia formułowane w ramach kolejnych uzgodnień z Bazylei (Basel Accord I, II, III) dotyczące nadzoru bankowego.

Taki uproszczony obraz społeczeństwa i jego zróżnicowany odbiór nowości, wynalazków, zmian obserwować można na każdym odcinku życia społecznego. Widać to wyraźnie w całej perspektywie historycznej poznania, gdzie każda rewolucja w nauce przyjmowana jest i co za tym idzie akceptowana z pewnym opóźnieniem w stosunku do daty danego wynalazku. Tak działo się w przeszłości, tak dzieje się i obecnie. Czas między wynalazkiem a jego upowszechnieniem zdecydowanie się skrócił, co jest konsekwencją rewolucji komunikacyjnej na świecie, niemniej jednak poszczególne wynalazki, odkrycia, rozwiązania nie są powszechnie akceptowane przez całość społeczeństwa jednocześnie. Część społeczeństwa nie tylko stawia opór przyjmowaniu nowych rozwiązań, ale wręcz je odrzuca. 
Jako skrajny przykład ilustrujący w sposób bardzo przerysowany zjawisko odrzucenia nowości może posłużyć populacja amiszy w USA (największe skupiska w rolniczych regionach stanów: Pensylwania, Ohio, Iowa, Missouri) ${ }^{25}$. Żyją oni według niepisanych zasad określanych jako Ordnung, są potomkami emigrantów ze Szwajcarii, którzy do Stanów i Kanady dotarli w latach 20. XVIII w. Populacja amiszy w Kanadzie i USA razem szacowana jest na $0,25 \mathrm{mln}$ i powoli rośnie. Społeczność ta nie jest jednorodna i dzieli się na mniejsze ugrupowania, jednak wspólną cechą tej społeczności jest odrzucenie nowych technologii. Niepisane zasady mówią o obowiązujących strojach, fryzurach, zachowaniu, zawodach, dopuszczalnych środkach transportu itp. W sumie w świecie amiszy czas zatrzymał się w XVIII w.

Specyficznymi amiszami w zakresie stosunków międzynarodowych jest duża część społeczeństw państw gospodarczo wysoko rozwiniętych, wschodzących i rozwijających się. Harmonizacja prawa, instytucji i liberalizacja w skali globalnej to całkowicie nowe warunki rozwoju, których wcześniej nie było, a więc nie można w tych rozwiązaniach stosować analogii czy porównań historycznych. Dodatkowym uwarunkowaniem o całkowicie nowym charakterze zarówno jeśli chodzi o skalę zjawiska, jak i liczbę państw nim objętych jest globalna współzależność. Jest to zjawisko całkowicie nowe, choć wielu osobom kojarzy się z zależnością. Zależność tworzy więzi jednostronne i oznacza relacje w pewnym sensie feudalne. Współzależność zaś tworzy zależności obustronne, gdzie państwo reprezentujące niższy poziom rozwoju również w relacjach międzynarodowych ma coś do powiedzenia, nawet w relacjach między takimi państwami jak USA i Wietnam czy Singapur. Przy czym jak można stwierdzić bardzo szybko, korzystając z powszechnie dostępnych źródeł statystycznych, potencjały USA i Wietnamu czy USA i Singapuru są nieporównywalne i szala przechyla się na korzyść USA. Na czym więc polega ta współzależność?

Pojęcie to zostało wprowadzone do analiz międzynarodowych przez dwóch amerykańskich badaczy stosunków międzynarodowych: J. Nye’a i R. Keohane’a ${ }^{26}$. Nie jest ono całkiem nowe, ale jak zawsze pewne zjawiska, nawet jeśli pojawiły się około 20 lat temu, nie jest to jednoznaczne $\mathrm{z}$ upowszechnieniem ich i w nauczaniu, i w percepcji relacji między państwami. Warto może w tym miejscu przypomnieć jeden z ekonomicznych kanonów z lat 60., który został wprowadzony przez R. Prebischa i znany jest jako terms of trade lub reguła Zingera-Prebischa. Obaj ekonomiści pokazywali, że państwa rozwijające się, specjalizując się w produkcji produktów rolnych, surowców czy nawet lekko przetworzonej formy surowców będą zawsze uzyskiwać

25 Amish Population Profile, Elizabethtown College, „The Young Center for Anabaptist and Pietist Studies" 2017.

26 R.O. Keohane, J.S. Nye, Power and Interdependence, Pearson Education, New York 2001, s. 228-264. 
niskie ceny, a jak zwiększą produkcję swych dóbr, które eksportują, to cena ich tym bardziej spadnie. Długotrwały trend w tym zakresie był spowodowany relatywnie małą dynamiką przyrostu produkcji przemysłowej w skali świata. Sytuacja zmieniała się jednak zasadniczo w warunkach przyspieszonej globalizacji, co stanowi konsekwencję trzech równoległych działań: 1) wejścia państw wysoko rozwiniętych w fazę postindustrialnego rozwoju; 2) przeniesienia produkcji na rynki o niższych kosztach pracy; 3) globalnego wzrostu konsumpcji. Wymienione trzy zjawiska oznaczają, że kraje rozwijające się również zaczynają konsumować, rynki w fazie postindustrialnej importują wyroby przemysłowe produkowane w gospodarkach wschodzących lub rozwijających się, w gospodarkach surowcowych podnosi się inwestycje angażowane w wydobycie, rozwijają się aglomeracje miejskie.

Zaściankowość wiedzy w tym zakresie widoczna jest wszędzie (w każdym państwie i w wielu dziedzinach) i świadczą o niej zarówno hasła wyborcze w USA, które wyniosły na fotel prezydencki D. Trumpa, jak i hasła głoszone w innych państwach, gdzie nawołuje się do reindustrializacji (m.in. Węgry czy Polska). Trump mówił m.in. o budowaniu muru na granicy z Meksykiem, wycofał swój kraj, który wcześniej był liderem liberalizacji, z wielu umów liberalizujących handel, w innych zapowiedział konieczność ich renegocjacji. Część swoich zapowiedzi wyborczych zrealizował, obejmując fotel prezydencki, przykładowo nie ratyfikował TPP i wycofał się z negocjacji TTIP ${ }^{27}$. Muru z Meksykiem nie zbudował i NAFTA nadal działa, choć wprowadzone od czerwca 2018 r. cła na stal, aluminium i panele solarne mają wpływ na wielkość produkcji i sprzedaży u największych dostawców oraz eksporterów tych produktów na rynek USA ${ }^{28}$. Posunięcia w tej dziedzinie wywołują kontrdziałania, określane jako retaliacje, ze strony m.in. ChRL czy UE, co potocznie określa się jako „wojny handlowe”. Jeśli chodzi o reindustrializację, to warto, nie wchodząc w szczegóły, przypomnieć, że sektor usług w języku angielskim również określa się jako service industry, czyli tłumacząc na polski, „przemysł usług” lub może, co lepiej brzmi w naszym języku, „sektor usług”.

Przemysł może wrócić do wszystkich gospodarek w fazie postindustrialnego rozwoju, ale nie da zatrudnienia tym, którzy wcześniej utracili pracę np. w fabrykach produkcji samochodów, gdyż powrót produkcji samochodów będzie oznaczał pełną robotyzację produkcji. Zastąpienie człowieka przy taśmie przez robota było możliwe od początku, ale park maszynowy mógł być jeszcze wykorzystany przez jakiś

27 K. Żukrowska, Rynek USA: pierwsze reakcje na wynik wyborów prezydenckich i realizacja haset gospodarczych z kampanii wyborczej, [w:] Amerykańskie wybory prezydenckie w erze postprawdy. Aktorzy, strategie, konteksty, red. J. Misiuna, M. Molęda-Zdziech, S. Łubiarz, Oficyna Wydawnicza SGH, Warszawa 2018, s. $19-49$.

28 US Exempts Some Allies From Tariffs but May Opt for Quotas, „The New York Times” 22.03.2018. 
czas w innych warunkach, ponadto bezpośrednie zastąpienie pracowników przez roboty nie byłoby proste $\mathrm{w}$ warunkach istnienia dobrze rozbudowanych struktur związków zawodowych. Procesowi zamykania dużych fabryk towarzyszyło zjawisko spadku „uzwiązkowienia” gospodarek. Ilustracją może tu być gospodarką USA, gdzie procesy te zaobserwowano najwcześniej i są obecnie najbardziej zaawansowane ${ }^{29}$. Ogólnie można stwierdzić szybszy spadek „uzwiązkowienia” w nowych państwach OECD z poziomu 80\% w 1985 r. do 8\% w 2015 r., podczas gdy w „starych” państwach członkowskich OECD analogiczne wskaźniki wynoszą 55\% (1985 r.) i 14\% (2015 r.) ${ }^{30}$.

Mierzenie otwarcia gospodarki jest zadaniem relatywnie łatwiejszym w porównaniu z próbą kwantyfikacji wskaźnika otwarcia społeczeństwa. W zasadzie w różnych dziedzinach różne cechy decydują o tym, czy dane społeczeństwo można uznać za otwarte. Przykłady otwartości, tolerancji, akceptacji różnorodności w różnych dziedzinach są rozmaite (patrz tabela 4).

Tabela 4. Zestawienie cech świadczących o stanie otwarcia społeczeństwa

\begin{tabular}{|c|c|c|c|}
\hline Cecha & $\begin{array}{l}\text { Znalezione przykłady } \\
\text { wskazujące na wage } \\
\text { danego problemu dla } \\
\text { społeczeństwa }\end{array}$ & Dokładniejsze wskazania & Ocena \\
\hline $\begin{array}{l}\text { Polityka wobec } \\
\text { imigrantów }\end{array}$ & $\begin{array}{l}\text { Bardzo zróżnicowany } \\
\text { stosunek: Finlandia (ponad } \\
\text { 70\% poparcia) po Włochy, } \\
\text { Czechy, Słowację, Estonię, } \\
\text { Łotwę, Belgię i Węgry } \\
(15-21 \%) \text {. }\end{array}$ & $\begin{array}{l}\text { Środek też zróżnicowany: } \\
\text { Francja, Niemcy, Austria, } \\
\text { Litwa (29-35\%) a Polska } \\
\text { i Wielka Brytania (36-42\%). }\end{array}$ & $\begin{array}{l}\text { Poziom życia określa kierunki } \\
\text { zainteresowania imigrantów, co } \\
\text { w różny sposób rzutuje na stan } \\
\text { akceptacji „obcych”. }\end{array}$ \\
\hline Polityka wobec LGBT & $\begin{array}{l}\text { Zróżnicowany poziom } \\
\text { tolerancji, związany } \\
\text { z dłuższym lub krótszym } \\
\text { okresem, w którym osoby } \\
\text { LGBT zaczęły się ujawniać. }\end{array}$ & $\begin{array}{l}\text { Różna polityka państwa } \\
\text { wobec osób LGBT. }\end{array}$ & $\begin{array}{l}\text { Jeden z wyznaczników tolerancji } \\
\text { społeczeństwa. }\end{array}$ \\
\hline $\begin{array}{l}\text { Możliwość zawierania } \\
\text { związków LGBT lub } \\
\text { inna forma prawna } \\
\text { akceptująca stały } \\
\text { związek (dziedziczenie) }\end{array}$ & $\begin{array}{l}\text { W części państw związki } \\
\text { takie są możliwe. W części } \\
\text { osoby LGBT, które zawarły } \\
\text { związek za granicą, } \\
\text { są szykanowane i nie } \\
\text { uznaje się ich ślubu. }\end{array}$ & $\begin{array}{l}\text { Alternatywą dla ślubu, } \\
\text { jeżeli prawodawstwo tego } \\
\text { rozwiązania nie dopuszcza, } \\
\text { powinna być inna forma } \\
\text { formalizacji takiego } \\
\text { związku, pozwalająca } \\
\text { np. dziedziczyć, odbierać } \\
\text { wyniki w szpitalu itp. }\end{array}$ & $\begin{array}{l}\text { Jest to jedna z dziedzin } \\
\text { wskazująca na ograniczoną } \\
\text { tolerancję społeczeństwa. }\end{array}$ \\
\hline
\end{tabular}

29 Trade Unions and the global crisis. Labour's visions, strategies and responses, red. M. Serrano, E. Xhafa, M. Fichter, International Labour Office, Geneva 2011, s. 66; A. Ozimek, Reinventing Unions for $21^{\text {st }}$ century, „Forbes” 29.10.2012; S. Cares, A. Garnero, S. Martin, The State of Trade Unions, Employer Organizations and Collective Bargaining in OECD Countries, OECD, Paris 2017.

30 Ibidem. 


\begin{tabular}{|c|c|c|c|}
\hline Cecha & $\begin{array}{l}\text { Znalezione przykłady } \\
\text { wskazujące na wage } \\
\text { danego problemu dla } \\
\text { społeczeństwa }\end{array}$ & Dokładniejsze wskazania & Ocena \\
\hline $\begin{array}{l}\text { Tłumaczenia obcej } \\
\text { literatury }\end{array}$ & $\begin{array}{l}\text { Jest to dziedzina } \\
\text { relatywnie najłatwiej } \\
\text { akceptowalna. Książki } \\
\text { są tłumaczone, zwłaszcza } \\
\text { literatura zdobywająca } \\
\text { międzynarodowe laury lub } \\
\text { zyskująca popularność za } \\
\text { granicą. }\end{array}$ & $\begin{array}{l}\text { Korzystna ocena tej } \\
\text { dziedziny wynika z tego, } \\
\text { że ludzie jeszcze czytają, } \\
\text { choć czytelnictwo ogólnie } \\
\text { spada. Są jednak inne } \\
\text { formy docierania z książką: } \\
\text { audiobooki, e-książki, } \\
\text { a nawet często filmy } \\
\text { nakręcone w oparciu } \\
\text { o książkę. }\end{array}$ & $\begin{array}{l}\text { Mało się robi dla promocji } \\
\text { narodowych osiagnię́c } \\
\text { w tej dziedzinie, na co mają } \\
\text { wpływ osoby zajmujące się } \\
\text { promocją kultury za granicą } \\
\text { w placówkach. Często ich } \\
\text { wiedza jest mało aktualna, } \\
\text { ograniczona, nieodpowiadająca } \\
\text { roli, jaką kultura może obecnie } \\
\text { pełnić w tworzeniu więzi } \\
\text { międzynarodowych. }\end{array}$ \\
\hline $\begin{array}{l}\text { Znaczenie religii } \\
\text { w życiua }\end{array}$ & $\begin{array}{l}\text { Średnio w USA (wg } \\
\text { Gallupa) od } 58 \% \text { w } 1992 \text { r. } \\
\text { do } 52 \% \text { w } 2016 \text { r. } \\
\text { Najwyższy poziom } \\
\text { wskaźnika } 61 \% \text { w latach } \\
1998 \text { i } 2002 .\end{array}$ & $\begin{array}{l}\text { Znaczenie religii w życiu } \\
\text { jest zróżnicowane } \\
\text { w zależności od } \\
\text { wiary. Najwyższe jest } \\
\text { u protestantów. }\end{array}$ & $\begin{array}{l}\text { Obserwuje się spadek znaczenia } \\
\text { u protestantów z } 69 \% \text { w } 1948 \text { r. } \\
\text { do } 37 \% \text { w } 2016 \text { r. Drugie miejsce } \\
\text { zajmują chrześcijanie - } 22 \% \text {, } \\
\text { mormoni, Żydzi - po } 2 \% \text {, } \\
\text { niewierzący } 18 \% \text {. }\end{array}$ \\
\hline $\begin{array}{l}\text { Inne świątynie niż } \\
\text { te reprezentujące } \\
\text { dominującą religię }\end{array}$ & $\begin{array}{l}\text { Coraz częściej obserwuje } \\
\text { się różne religie, różne } \\
\text { świątynie i tolerancję dla tej } \\
\text { różnorodności. }\end{array}$ & $\begin{array}{l}\text { Elementem wspólnym } \\
\text { może być uniwersalne } \\
\text { wykorzystanie świątyń, tak } \\
\text { jak to np. jest widoczne } \\
\text { w ewolucji czéści } \\
\text { świątyń w Europie, które } \\
\text { były meczetami, potem } \\
\text { kościołami, synagogami } \\
\text { czy cerkwiami. }\end{array}$ & $\begin{array}{l}\text { Koszt ziemi może być } \\
\text { rozwązaniem mobilizującym do } \\
\text { organizowania się spoteczności } \\
\text { lokalnej i budowania świattyń } \\
\text { o charakterze uniwersalnym. } \\
0 \text { ich określonym przeznaczeniu } \\
\text { powinny decydować wystawione } \\
\text { symbole i celebrujący } \\
\text { kaznodzieja. }\end{array}$ \\
\hline $\begin{array}{l}\text { Akceptacja i ciekawość } \\
\text { innych przepisów } \\
\text { kulinarnych, restauracje }\end{array}$ & $\begin{array}{l}\text { W wielu państwach } \\
\text { spoteczność odrębna } \\
\text { kulturowo wprowadza } \\
\text { swoje produkty na dany } \\
\text { rynek w sposób naturalny. }\end{array}$ & $\begin{array}{l}\text { Powstają restauracje, } \\
\text { sklepy ze specjałami, } \\
\text { cukiernie, co automatycznie } \\
\text { oznacza promieniowanie } \\
\text { danej kultury } \\
\text { na społeczeństwo. }\end{array}$ & $\begin{array}{l}\text { Kuchnia jest czynnikiem } \\
\text { przybliżającym społeczeństwa. } \\
\text { Pokazuje pewne wspólne } \\
\text { kulinarnie potrawy oraz także } \\
\text { i ich zróżnicowanie. }\end{array}$ \\
\hline $\begin{array}{l}\text { Turystyka } \\
\text { międzynarodowa, } \\
\text { odsetek społeczeństwa } \\
\text { podróżujący za granicę }\end{array}$ & $\begin{array}{l}\text { Rośnie odsetek } \\
\text { społeczeństwa } \\
\text { podróżującego. }\end{array}$ & $\begin{array}{l}\text { Więcej jest biur podróży } \\
\text { z różną ofertą dla różnych } \\
\text { konsumentów usług } \\
\text { turystycznych. }\end{array}$ & $\begin{array}{l}\text { Dla wielu osób poprawiła się } \\
\text { zdolność korzystania z ustug } \\
\text { tego rodzaju. }\end{array}$ \\
\hline $\begin{array}{l}\text { Stosunek do turystów } \\
\text { zagranicznych w kraju }\end{array}$ & $\begin{array}{l}\text { Na ogół stosunek do } \\
\text { turystów jest dobry, } \\
\text { przyjacielski, pomocny. }\end{array}$ & $\begin{array}{l}\text { Istnieje poczucie, że jest } \\
\text { to sektor dający dodatkowe } \\
\text { dochody w każdej } \\
\text { gospodarce. }\end{array}$ & $\begin{array}{l}\text { Powinno się otwarcie mówić } \\
\text { o znaczeniu gałęzi turystyki } \\
\text { dla gospodarki na każdym } \\
\text { rynku. Informacja ta powinna } \\
\text { być podawana w sposób } \\
\text { akceptowalny przez przeciętnego } \\
\text { obywatela. }\end{array}$ \\
\hline $\begin{array}{l}\text { Filmy zagraniczne i ich } \\
\text { popularność w danym } \\
\text { kraju }\end{array}$ & $\begin{array}{l}\text { Oddziaływanie silne. } \\
\text { Konieczne działania } \\
\text { interwencyjne, wspierające } \\
\text { działania. }\end{array}$ & $\begin{array}{l}\text { Dotyczy to filmów } \\
\text { fabularnych, telewizyjnych, } \\
\text { seriali, częściej powinny } \\
\text { być przygotowywane } \\
\text { we współpracy } \\
\text { międzynarodowej. }\end{array}$ & $\begin{array}{l}\text { Polityka narodowa powinna } \\
\text { wspierać promocję kultury. } \\
\text { Powinni to robić odpowiednio } \\
\text { przygotowani do tego eksperci. }\end{array}$ \\
\hline $\begin{array}{l}\text { Sztuki zagraniczne } \\
\text { grane w teatrach } \\
\text { w danym kraju }\end{array}$ & $\begin{array}{l}\text { Dość powszechne } \\
\text { zjawisko, chociaż } \\
\text { import i eksport nie } \\
\text { są tu zrównoważone. }\end{array}$ & $\begin{array}{l}\text { W nowych państwach } \\
\text { UE brak odpowiedniej } \\
\text { polityki zagranicznej w tym } \\
\text { zakresie. }\end{array}$ & $\begin{array}{l}\text { Konieczne wsparcie w postaci } \\
\text { przygotowanych instrumentów, } \\
\text { informacji, siła oddziaływania } \\
\text { olbrzymia. }\end{array}$ \\
\hline
\end{tabular}




\begin{tabular}{|l|l|l|l|}
\hline \multicolumn{1}{|c|}{ Cecha } & $\begin{array}{l}\text { Znalezione przykłady } \\
\text { wskazujące na wage } \\
\text { danego problemu dla } \\
\text { społeczeństwa }\end{array}$ & Dokładniejsze wskazania & \multicolumn{1}{|c|}{ Ocena } \\
\hline $\begin{array}{l}\text { Wystawy zagranicznych } \\
\text { malarzy organizowane } \\
\text { w krajowych galeriach } \\
\text { i zainteresowanie nimi }\end{array}$ & $\begin{array}{l}\text { Koncentracja na własnych } \\
\text { malarzach lub dzieła } \\
\text { sprowadzane z zagranicy. } \\
\text { Wystawy malarzy epoki lub } \\
\text { jednego twórcy. }\end{array}$ & $\begin{array}{l}\text { Wymiana między galeriami. } \\
\text { Organizacja kosztowna. } \\
\text { Mniejsze możliwości } \\
\text { w mniejszych państwach. }\end{array}$ & $\begin{array}{l}\text { Wymiana taka ma miejsce. } \\
\text { Współpraca między galeriami jest } \\
\text { dość powszechna w państwach } \\
\text { UE i szerzej OECD. }\end{array}$ \\
\hline
\end{tabular}

a Ważnym czynnikiem wydaje się tu być definiowanie tego, kto jest zaliczany do grupy „wierzących”, a kto do grupy „niewierzących”, tzn. czy odnosi się to do religii większości i pozostałych wiernych, czy grupa „pozostałych” wiernych wliczana jest do „wierzących”.

Źródło: Opracowanie własne $\mathrm{n}$ apodstawie: Attitudes towards Immigration and their Antecents: Topline Resultsfrom Round 7 of the European Social Survey, November 2016; In depth Gallup Survey on Religion, Gallup USA 2017.

Wskaźników służących do charakteryzacji społeczeństw pod względem ich otwarcia jest więcej. Powyżej podano kilka, z czego część dotyczy kwestii wewnętrznych, inne zewnętrznych lub mają charakter mieszany. Filozofia czy socjologia tradycyjnie zajmują się problemem badania społeczeństw pod kątem podatności na zmiany mniej lub bardziej rewolucyjne. Jednym z takich mierników, który można zakwalifikować jako klasyczny, jest warunek kontynuacji sformułowany przez Leibniza ${ }^{31}$. CCL (continuation conditions of Leibnitz, warunki kontynuacji Leibnitza) zakłada pewną inercję społeczeństwa w przyjmowaniu nowości. Uzasadnia to następująco: jeśli coś kształtowane jest w określonych ramach, nie może wyjść poza te ramy. W tym przypadku ramy tworzą dotychczasowe doświadczenie, wiedza, percepcja, interpretacja warunków itp. Pewną korektę do tej koncepcji wprowadza G. Priest, który twierdzi, że za inercję odpowiedzialna jest w dużym stopniu przyczynowość, czyli to, co jest przyczyną zmian, a także w jaki sposób te zmiany zostały przedstawione społeczeństwu $^{32}$. Priest nie odrzuca koncepcji Leibnitza, ale uzupełnia ją, wprowadzając pewne uściślenia, które mogą wyjaśniać, dlaczego jedni przyjmują nowość szybciej, inni zaś wolniej lub w ogóle bronią się przed przyjęciem innych, nowych rozwiązań. Priest traktuje odrzucenie kontynuacji jako kaprys, ekstrawagancję, na którą nie stać wszystkich ze względu na przeciwstawianie się powszechnie obowiązującym zasadom czy powszechnie stosowanym rozwiązaniom. Niemniej według socjologów i filozofów ludzie są w stanie przyjąć zmiany w określonych warunkach, w których widzą wyższy cel, uzasadniony nie przez powszechnienie znane, ale nie do końca akceptowane warunki panujące w ich państwie, zastępując je rozwiązaniami nowymi. W tym

31 Ch.E. Mortensen, The Leibnitz Continuity Condition, Inconsistency and Quantum Dynamics,1997, Oai:digital.library.adelaide.edu.au:2440/1607

32 G. Priest, Paradoxical Truth, „The New York Times” 28.11.2010, https://opinionator.blogs.nytimes. com/2010/11/28/paradoxical-truth/ 
przypadku punktem wyjścia nie jest przeszłość danego państwa i stosowane w nim wcześniej rozwiązania, ale jego przyszłość. Ta przyszłość może mieć wiele rozwiązań z przeszłości, mogą one jednak omijać okres odrzucany, niechciany - hasłowo lub rzeczywiście ${ }^{33}$. R. Holton natomiast zwraca uwagę na problem narastania nacjonalizmów, etniczności, zakorzenienia narodowej kultury i jej hegemoniczności. W kontekście przeprowadzonych analiz zadaje pytanie, czy obserwowane działania są wynikiem upadku, czy ochrony państwa narodowego, zadaje pytanie, czy bitwa ta o państwo narodowe może okazać się zwycięska ${ }^{34}$ ? Pytania te pozostawia się bez odpowiedzi, nie można bowiem przewidzieć, w którym kierunku ostatecznie będzie podążać świat ${ }^{35}$.

Przykładowo w Polsce może to być hasło odrzucenia komunizmu i deklaracja przywrócenia pewnych rozwiązań z okresu międzywojennego, kiedy Polska była rządzona autorytarnie. Faktycznie przedwojenny autorytaryzm i autorytaryzm komunistyczny miały wiele wspólnych cech. Założona koncepcja nawiązania do przeszłości opiera się na prostej koncepcji „sprzedania” wyborcom, że „czyści się pozostałości komuny". Odrzuca się tym samym demokrację, zastępując ją prawem autorytarnym, odcinając równocześnie Polskę od UE i jej demokratycznych struktur, co w warunkach przyjętej polityki izolacjonizmu pozostawia nasze państwo w pasie między Rosją, która stara się odbudowywać swoje wpływy w regionie byłego ZSRR krok po kroku, a UE, która przechodzi głębokie zmiany w zasadach finansowania, prowadzonej polityki i określenia przyszłej koncepcji integracji.

\section{Problem równowagi}

Wiedza i mierniki dotyczące otwarcia gospodarki są zdecydowanie bardziej zaawansowane niż wiedza i mierniki dotyczące otwartości społeczeństw. Nie ulega wątpliwości, że brak symetrii między otwarciem gospodarki a otwartym społeczeństwem może być źródłem napięć społecznych, politycznych i gospodarczych i takie napięcia zaczyna wywoływać. Widoczne to jest w USA, Wielkiej Brytanii, Grecji czy na Węgrzech i w Polsce. Część państw z tej listy reprezentuje niski poziom „uzwiązkowienia" (np. USA, W. Brytania, Polska), podczas gdy pozostałe relatywnie wysoki (np. Grecja). Dotyczy więc zarówno państw, które były zwolennikami globalnej

33 R. Gellately, Lenin, Stalin, Hitler: The Age of Social Catastrophe, Vintage, London 2008, s. 41 (Rosja) i s. 81 (Niemcy).

34 R.J. Holton, op.cit., s. 220-237.

35 Ibidem, s. 234. 
liberalizacji i liderami tego procesu (USA i W. Brytania), jak i państw reprezentujących relatywnie wysoki poziom rozwoju, ale borykających się z problemami polityki fiskalnej i relatywnie niskiej dynamiki wzrostu, czemu towarzyszy niska stopa życiowa ludności (Grecja), a także nowych państw członkowskich UE, które skorzystały na członkostwie w UE (Polska i Węgry).

Problemem jest tu kwestia powszechnej edukacji w sprawie korelacji między otwarciem gospodarki a wzrostem i rozwojem. Mierników, które to potwierdzają, jest kilka. Najważniejsze z nich to poziom PKB (wielkości bezwzględne), wielkość obrotów handlowych i kapitałowych (wielkości bezwzględne i względne) czy PKB per capita (wielkość względna) oraz Human Development Index (Indeks Rozwoju Kapitału Ludzkiego, też wielkości bezwzględne).

Państwa wymienione jako krytycznie nastawione do procesów globalizacji czy integracji, czego dowodem są toczące się w nich dyskusje na temat przyszłości polityki gospodarczej, zaliczane są obecnie do grupy o najwyższych wskaźnikach HDI. Pierwsza dziesiątka obejmuje: Norwegię, Australię i Szwajcarię (2), Niemcy, Danię i Singapur (5), Holandię, Irlandię, Islandię oraz Kanadę i USA (10). Wielka Brytania ma 16 miejsce, Czechy 28, Polska 36, a Węgry 43. Ta grupa o najwyższych wskaźnikach HDI to 51 państw. Wysoki wskaźnik to państwa na pozycji 52-105, gdzie listę otwiera Białoruś, a zamyka Uzbekistan. Poziom średni to pozycje 107-147, listę otwiera tu Mołdawia, a zamyka Pakistan. Niski wskaźnik to państwa plasujące się na pozycjach 148-188, gdzie listę otwiera Suazi, a zamyka Afryka Środkowa ${ }^{36}$.

Patrząc na wzmiankowane listy i ruchy na nich wymienionych państw, możemy jednoznacznie stwierdzić, że poziom dobrobytu zależy w dużym stopniu od prowadzonej w danym państwie polityki gospodarczej. Państwa otwarte mają wskaźniki na ogół wysokie, państwa zamknięte - niskie. Jeszcze można wskazać grupę gospodarek, które starają się nadrobić lukę rozwoju. Jeśli mają one rynki otwarte, jest to jeden z warunków wspomagających rozwój przez wysoką dynamikę wzrostu. Również widoczne są spadki w pozycjach na liście HDI państw, które zaczynają wprowadzać rozwiązania oznaczające protekcję swoich gospodarek lub nawet tylko deklarację wskazującą na intencję takiej ochrony.

Asymetria równowagi między otwarciem gospodarki a otwarciem społeczeństw prowadzi do napięć politycznych i odwrócenia warunków, które wcześniej decydowały o wzroście gospodarczym. Widoczne to jest w wielu państwach, czego skrajnymi ilustracjami mogą być hasła głoszone w kampanii poprzedzającej referendum w Wielkiej Brytanii na temat Brexitu czy kampania wyborcza we Francji, w której wysoko była notowana partia Marie Le Pen, Ruch Narodowy, i głoszone przez nią

36 Human Development Report 2016, UN, New York 2016. 
hasła. Podobnie można oceniać wydarzenia w Budapeszcie i Warszawie, a także nastroje w Pradze i Bratysławie. Politycznej odwadze w odrzucaniu wsparcia prawno-insytucjonalnego, a co za tym idzie i finansowego sprzyja koniunktura i fakt, że na razie wszystkie wymienione państwa i ich rynki mają dostęp do rynku, który stanowi największego odbiorcę ich eksportu. Należy jednak zadać pytanie, co się stanie, gdy koniunktura się pogorszy? Jakie nastroje społeczne pojawią się w tych państwach, co stanowiło kierunek je określający? Czy wywoła to narastanie napięć społecznych? Jak zareaguje na to władza? Jaka będzie reakcja polityków, którzy tę władzę będą sprawować? Powrót na ścieżkę demokratycznych reform w takiej sytuacji może być $z$ wielu względów trudny. Nie będzie niemożliwy, ale zajmie więcej czasu, będzie bardziej kosztowny z punktu widzenia społeczeństwa. Nakłady finansowe, potrzebne do przeprowadzenia tych zmian, będą również wyższe. Jest to scenariusz bardzo pesymistyczny. Niemniej taki rozwój wydarzeń wydaje się być bardzo realny.

Pewną szansą jest to, że odrzucenie jednej partii nie oznacza, że partia zwycięska utrzyma stałą przewagę, choć pewnym zagrożeniem może być zmiana rozwiązań prawnych i instytucjonalnych. Najłatwiej przeprowadza się radykalne zmiany, gdy społeczeństwo z takich czy innych względów obdarza rządzących kredytem zaufania. Tak było np. bezpośrednio po wojnie w państwach Europy Zachodniej, a także po zakończeniu zimnej wojny w 1989 r. Obecnie obserwujemy pewne przetasowania zarówno w państwach uznanych za liderów międzynarodowych, jak i w samych organizacjach międzynarodowych (MFW, WTO) czy integracyjnych (UE). Przy czym przetasowania to słowo nieodzwierciedlające zachodzących głębokich zmian w rozwiązaniach na poziomie państw i w układach międzynarodowych. Część państw i ich gospodarki wymagają głębokich reform, które bardziej widoczne są w gospodarce brytyjskiej czy irlandzkiej, mniej w gospodarce niemieckiej i francuskiej. Konieczne jest wprowadzenie europejskich instrumentów wspierających taki kierunek zmian, które będą miały charakter strukturalny i zarazem systemowy (większa samodzielność podmiotów oraz jednostek).

Brak równowagi między otwarciem gospodarki i otwarciem społeczeństwa staje się widoczny w warunkach kryzysowych, a $\mathrm{z}$ takim stanem mamy do czynienia od pewnego czasu obecnie. Obejmuje to zarówno pewne zjawiska globalne, np. terroryzm, Państwo Islamskie (ISIS/Daesh), kryzys finansowy 2008+ i jego długotrwałe konsekwencje, jak i zjawiska regionalne: kryzys UGiW, Brexit i jego konsekwencje budżetowe dla UE, kryzys uchodźczy. Ponadto, jak wspominano wcześniej, wiele państw boryka się z wewnętrznymi napięciami, które mają różne podłoże (zła polityka gospodarcza, nadmierna opiekuńczość państwa, ciężar podatków, ucieczka od płacenia wysokich podatków do rajów podatkowych czy niski poziom ściągalności podatków). 
Likwidacja asymetrii między otwarciem gospodarki a otwarciem społeczeństwa nie jest możliwa w krótkim czasie. Cele w tym zakresie powinny być określone już obecnie. Podobnie należy podejść do wyznaczenia niezbędnych kierunków działania. Urzeczywistnianie tych celów zajmie kilka, jeśli nie kilkanaście lat. Likwidacja powinna objąć systemy edukacyjne, rozwiązania prawne, instytucjonalne, kulturowe itp. Działania powinny być wielopłaszczyznowe, czyli pewne elementy takiej polityki powinny znaleźć się w mediach, filmach, publikacjach. Nie należy jednak podchodzić do tego problemu tak jak podchodziło się do osiągania pewnych celów propagandowych, gdyż skutek może być odwrotny od oczekiwanego. Można tu zasięgnąć wiedzy ze źródeł pochodzących z państw, gdzie podobne problemy rozwiązywano. Chodzi tu o doświadczenia z USA, Wielkiej Brytanii, Australii, Nowej Zelandii czy RPA.

Jeśli zaobserwowana asymetria nie zostanie zniwelowana, a następnie wyeliminowana, nie można będzie mieć pretensji o zahamowanie procesów integracyjnych w Europie czy w szerszym, globalnym zakresie. Trudno zakładać, że np. Polacy powinni pracować w innych państwach członkowskich UE, natomiast Polska nie będzie przyjmować pracowników z zagranicy. Taka filozofia przypomina prostą filozofię Kalego. Kali - tak, Kalemu - nie. Filozofia taka ma głębokie korzenie oparte na egoizmie, trudno jednak być egoistą, gdy działa się w szerszej, wielonarodowej grupie. Wielonarodowość i umiędzynarodowienie kontaktów, procesów produkcji we wszystkich sferach pogłębi się w efekcie rewolucji 4.0. Podstawy do tego procesu dała rewolucja 3.0. Nie wszystkie jednak firmy i ich pracownicy są do tego przygotowani. To też ważny aspekt strategii otwierania społeczeństwa.

Zniesienie zaobserwowanej asymetrii wymaga określenia celów, etapów realizacji konkretnych zadań opracowanych w ramach przyjętej strategii w tym zakresie i realizacji konkretnych działań zakładanych w ramach prowadzonej polityki. Powinno to objąć cele polityczne, zmiany w programach edukacyjnych wszystkich szczebli, politykę informacji, uwzględnienie problemu w mediach czy nawet szerzej w kulturze (publicystyka, książka, film, malarstwo, kulinaria itp.). Bez zakrojonych kompleksowo działań utrzymuje się warunki do łatwej manipulacji rzeszą wyborców, których wiedza na temat „otwierania społeczeństwa” jest bardzo ograniczona. To będzie potęgowało napięcia społeczne i frustracje, może nawet prowadzić do otwartych konfliktów społecznych, czego można uniknąć w warunkach stosowania odpowiedniej polityki. 


\section{Równowaga i jej warunki}

Dążenie do równowagi między otwarciem gospodarki a otwieraniem społeczeństwa powinno przewidywać dynamikę rozwoju obu procesów. Nie można zakładać, że otwarcie gospodarki pozostanie na obecnym etapie i nie będzie poszerzać się w przyszłości. Wystarczy założyć kolejne poszerzenie UE, co będzie jednoznaczne z poszerzeniem otwarcia każdej gospodarki państwa członkowskiego. Podobnie należy traktować każdą umowę stowarzyszeniową UE czy rozwiązania negocjowane w ramach umów o wolnym handlu przez UE (CETA, zawieszona w styczniu $2017 \mathrm{r}$. umowa TTIP, czy umowy wynegocjowane, ale niepodpisane lub nieratyfikowane, a także umowy negocjowane). Przykładem umów negocjowanych są umowy UE z Japonią, Nową Zelandią, Indiami, ASEAN (Indonezja, Malezja, Tajlandia, Filipiny), Mercosur (Argentyna, Brazylia, Paragwaj, Urugwaj, Wenezuela). UE negocjuje też Głębokie Wszechstronne Umowy o Wolnym Handlu z Maroko i Tunezją. Negocjowane też są umowy z GCC (Bahrajn, Kuwejt, Oman, Katar, Arabia Saudyjska, Zjednoczone Emiraty Arabskie). Wymienione umowy nie wyczerpują listy, która obejmuje dodatkowo Singapur, Wietnam, Wspólnotę Wschodnioafrykańską (Burundi, Kenia, Rwanda, Tanzania, Uganda). UE wynegocjowała warunki umów o wolnym handlu, które jednak dotąd nie zostały podpisane lub ratyfikowane przez strony. Są to umowy z Beninem, Burkiną Faso, Wyspami Zielonego Przylądka, Wybrzeżem Kości Słoniowej, Gambią, Gwineą, Gwineą Bissau, Liberią, Mali, Nigrem, Nigerią, Senegalem, Sierra Leone, Togo i Mauretanią ${ }^{37}$.

Oprócz umów negocjowanych na zasadach bilateralnych negocjowane są również umowy wielostronne. Przykładem umowy wielostronnej w skali globalnej są negocjacje prowadzone w ramach WTO (runda dohijska). Inne umowy obejmują: TiSA (Trade in Service Agreement), negocjowany przez UE i wybrane państwa wysoko rozwinięte (Australia, Kanada, Chile, Hongkong, Islandia, Izrael, Japonia, Korea Płd., Liechtenstein, Nowa Zelandia, Norwegia, Szwajcaria, Tajwan, USA, Urugwaj), średnio rozwinięte (Kolumbia, Kostaryka, Meksyk, Panama), a także słabo rozwinięte (Pakistan, Paragwaj). Wiele rozwiązań jest koordynowanych w ramach G7 czy szerzej w ramach G20, gdzie stroną wspólnych ustaleń jest UE. W ramach G20 ustalenia wspólne nie ograniczają się do koordynacji polityki finansowej, ale obejmują i inne sektory gospodarki (praca i zatrudnienie, sprawy zagraniczne, przedstawiciele banków centralnych i ministerstw finansów).

37 Przygotowano na podstawie: https://eeas.europa.eu/headquarters/headquarters-homepage/area/geo_ en [dostęp 12.09.2017]. 
Lista pokazuje, że negocjacje trwają. Pesymistycznie można zakładać, że ich rezultaty w obecnych warunkach stoją pod znakiem zapytania. Optymistycznie można zakładać, że prowadzone negocjacje przyniosą określone rezultaty w liberalizacji. UE jest rynkiem znajdującym się w centrum procesów liberalizacyjnych, jest stroną umów dwustronnych i wielostronnych. Tym samym problem pogłębiania asymetrii między otwarciem rynków a otwarciem społeczeństwa nie tylko będzie trwałym zjawiskiem, ale można przewidywać jego narastanie, o czym decydują wskazane fakty.

Rozwiązywanie problemu otwarcia społeczeństwa i zamykania luki między otwieraniem gospodarki a otwarciem społeczeństwa nie może być pozostawione do realizacji wyłącznie na poziomie narodowym, powinno być wsparte na poziomie międzynarodowym ${ }^{38}$. Pewne elementy takiej polityki są obecne w wachlarzu dostępnych instrumentów UE, czego przykładem może jest program Erasmus, stwarzający warunki do wymiany uczniów, studentów i pracowników akademickich, podobnie może być traktowany program finansowania badań w ramach Programów Ramowych UE. Działania te nie wyczerpują jednak tematu, gdyż problem jest szerszy.

Konieczne jest przygotowanie listy celów, które każdy kraj członkowski UE powinien urzeczywistniać zgodnie $\mathrm{z}$ narodową specyfiką ${ }^{39}$. Osiąganie tych celów powinno być wsparte określonymi środkami finansowymi. Bez takiego działania asymetria między otwarciem gospodarki i otwarciem społeczeństw nie tylko może być postrzegana jako czynnik hamujący integrację i jej postęp, będzie również silnym ograniczeniem dla akceptacji społecznej umów międzynarodowych, których stroną jest UE. Napięcia z tym związane mogą hamować przyszły rozwój UE i jej państw członkowskich. Brak postępu w niwelowaniu asymetrii między otwarciem gospodarki a otwartym społeczeństwem może nawet być uznane za rozwiązanie, które może doprowadzić do stopniowego spłycania procesów integracji.

Zapowiedzią takich możliwości jest obecnie negocjowany Brexit, a także wcześniej formułowane opinie o możliwości wyjścia Grecji (Grexit, Italexit czy rozważany Polexit). Sprawa wydaje się poważna, o czym decydują nie tylko obserwowane protesty przeciwko negocjowanym umowom o wolnym handlu, ale również możliwość blokowania każdej innej umowy, która jest wynegocjowana i wymaga ratyfikacji. Dla wielu państw brak perspektywy bliższej współpracy z rynkiem UE działa demobilizująco na dynamikę zmian. Ilustracją takiej tendencji może być protest Holandii przeciwko stowarzyszeniu Ukrainy z UE (6.04.2016 r.).

38 R. Vos, E. Ganuza, S. Morley, Sh. Robinson, Who Gains from Free Trade. Export-led growth, inequality andpoverty in Latin America, Routledge Studies in Development Economics, London- New York 2006, s. 8.

39 R.J. Holton, op.cit., s. 174. 
Otwarcie gospodarki jest wymuszane przez międzynarodowy podział pracy, w którym przeszło się od specjalizacji międzygałęziowej do wewnątrzgałęziowej. Liberalizacja i rewolucja 3.0 doprowadziły do powstania globalnych łańcuchów tworzenia wartości dodanej (GVC). Rozwiązania tu obserwowane są też warunkiem zmian strukturalnych poszczególnych rynków, które wymuszają wszechstronne zmiany w całej gospodarce, począwszy od systemów edukacyjnych, przez sektor produkcji, na usługach kończąc, w tym w sferze zdrowia, opieki nad ludźmi starymi, spędzania wolnego czasu, metod komunikowania się. Bez procesu otwierania gospodarki i zmian strukturalnych obserwowanych na wszystkich rynkach bez względu na poziom ich rozwoju niska dynamika wzrostu gospodarczego obserwowana w gospodarkach wysoko rozwiniętych byłaby jeszcze niższa. Tym samym konkurencja ze strony rynków wschodzących może być uznana za stymulator zmian, sprzyjający przeobrażeniom strukturalnym, co umożliwia wejście w segmenty produkcji o wyższej wartości dodanej. Niemniej zmiany te wymagają odpowiedniego przygotowania siły roboczej, której stawia się nowe wymogi odnoszące się do wykształcenia, kompetencji, zdolności i zawodów. Zmiany w tym zakresie mogą ulec przyspieszeniu wraz z zaawansowaniem rewolucji przemysłowej 4.0 i wdrażania robotyzacji oraz sztucznej inteligencji. Pełnych skutków tych procesów nie jesteśmy jeszcze dzisiaj w pełni ocenić. Wiemy jednak, że procesy w tym zakresie będą się nasilać, co oznacza, że im wcześniej przygotowuje się społeczeństwo do takich przeobrażeń, tym niższe będą ich koszty, czemu powinno towarzyszyć relatywnie płynne dostosowywanie się do zmieniających się warunków.

Literatura przedmiotu nie dostarcza jednoznacznej odpowiedzi, który ze scenariuszy zwycięży w skali globalnej: powrót do protekcji i zamykania gospodarki, separacji społeczeństw o różnych korzeniach etnicznych czy próba doprowadzenia do symetrii między otwieraniem gospodarki a otwieraniem społeczeństw. Patrząc na ten problem na poziomie makro, nie sugeruje się nawet specyficznych rozwiązań, które mogłyby sprzyjać takiej symetrii. Nie ulega jednak wątpliwości, że takie działania powinny obejmować przede wszystkim sferę edukacji, począwszy od wiedzy na temat świata już w wieku przedszkolnym. Patrząc na dynamikę zmian obserwowanych w ostatnich latach, czego najprostszym dowodem jest stwierdzenie, że pierwsze rewolucje przemysłowe następowały po sobie w odstępach około stuletnich, to obecnie mamy do czynienia z odstępami 20-30-letnimi.

Najnowsza rewolucja przemysłowa 4.0 oznacza szybki przepływ informacji, możliwość taniego przemieszczania się z kontynentu na kontynent, dynamiczne umiędzynarodawianie się gospodarek, zacieśnianie więzi produkcyjnych w ramach GVC. Rewolucja ta niesie konieczność akceptacji szybkich zmian produkcji, a co za tym idzie i przyzwyczajeń konsumenckich. Od strony podażowej siły roboczej prowadzi 
to do nowych kwalifikacji, zdolności, elastyczności rynku i odpowiednich rozwiązań prawno-instytucjonalnych. Próba protekcji może opóźniać pewne procesy, ale ich nie zmieni. Widać to na przykładzie wielu gospodarek prowadzących politykę protekcji własnych rynków, w których polityka ta utrzymywała pewną liczbę miejsc pracy, podwyższając koszty produkcji, nie wyeliminowała jednak presji na ich likwidację. Wpłynęła jednak na koszty utrzymywania konkurencyjności i ostatecznie wpłynęła na jej obniżenie. Na sprawę otwartości społeczeństw i otwartości gospodarki należy spojrzeć realnie. Przyszłość gospodarki światowej to model oparty na rynku wewnętrznym UE, jeśli użyjemy odniesienia, które znamy. Tym samym mając to na uwadze, należy się do tego przygotowywać. Zamykanie oczu, jak to robią małe dzieci, myśląc, że jak one nie widzą, to również nie są widziane przez otoczenie - nie jest dobrym rozwiązaniem, bo nie zmienia rzeczywistości. Zamykanie oczu może zatrzymać czy spowolnić jakiś proces, jednakże każde spowolnienie oznacza wyższe koszty wymierne, finansowe i mniej wymierne społeczne.

\section{Podsumowanie}

Przeprowadzona analiza wskazuje, że asymetria między otwarciem gospodarki i otwartym społeczeństwem jest problemem w większości państw wysoko rozwiniętych. Łatwiej jest mierzyć otwarcie gospodarki niż otwartość społeczeństwa, co może być uznane za jedno z ograniczeń likwidowania problemu asymetrii. Występowanie asymetrii bez ingerencji, której celem byłaby niwelacja występującej tu luki i jej stopniowa eliminacja, może ograniczyć integrację regionalną i być źródłem napięć politycznych w tych krajach. Przejawy takich problemów obserwowane są już w wielu państwach, a można przewidywać ich narastanie. Opinia ta uzasadniona jest tym, że planowane są nowe umowy liberalizacyjne o charakterze bilateralnym i wielostronnym. Ponadto współczesna gospodarka napędzana kolejnymi rewolucjami przemysłowymi staje się bardziej otwarta i umiędzynarodowiona, o czym świadczą m.in. GVC (globalne łańcuchy tworzenia wartości dodanej), a nie jest to jedyna cecha współczesnej gospodarki decydująca o konieczności liberalizowania jej kontaktów $\mathrm{z}$ otoczeniem międzynarodowym.

Każdy kraj, każde państwo powinno przygotowywać się indywidualnie do tych zmian. Nie ulega jednak wątpliwości, że wspomaganie na szczeblu międzynarodowym: regionalnym, ponadregionalnym i globalnym może być uznane za konieczne wspomaganie takich procesów. Im wcześniej zacznie się redukować asymetrię w tym zakresie, tym niższe będą koszty tego procesu, które nie mogą być ograniczone 
wyłącznie do wymiaru finansowego, choć i finanse mają tu duże znaczenie. Koszty finansowe mogą być poszerzone przez koszty społeczne, polityczne, utraty dynamiki wzrostu, ograniczone możliwości finansowania zobowiązań państwa wynikające z systemów emerytur, obowiązku finansowania szkolnictwa, sektora zdrowia, różnego rodzaju rent, dodatków dla rodzin wielodzietnych, obronności, bezpieczeństwa wewnętrznego itp.

Problem dążenia do niwelowania asymetrii, oznaczający dążenie do symetrii między otwarciem gospodarki i społeczeństw, nie powinien być oparty na koncepcji spowolnienia otwierania gospodarki, ale na podjęciu wysiłku dynamizacji otwierania społeczeństw. W praktyce proces ten powinien być oparty na działaniach dwojakiego rodzaju: $\mathrm{z}$ jednej strony utrzymania dynamiki otwierania gospodarki, co oznacza kontynuację tego procesu, z drugiej zaś na przyspieszeniu i dynamizacji procesu otwierania społeczeństw. W obu przypadkach każde państwo powinno wprowadzać swoje własne rozwiązania, które przy pewnym wyprzedzeniu w stosunku do otoczenia może przynieść oczekiwane korzyści: wymierne i niewymierne. Będą one dotyczyć poprawy konkurencyjności, atrakcyjności rynku dla inwestorów, wejścia w niszowe specjalizacje, które mogą być przyszłościowe w związku z kierunkiem zmian gospodarczych i społecznych. Polityka taka i zmiany w jej ramach wprowadzone mogą ograniczać ubóstwo, wykluczenie, analfabetyzm wtórny, wiele chorób cywilizacyjnych. Należy tylko określić cele i wyznaczyć sposób ich osiągania, dzieląc na etapy, wyznaczając priorytety, a także źródła finansowania. Warto od razu wyjaśnić, że podatkowe źródła finansowe powinny być tu wykorzystywane w ograniczonym stopniu.

\section{The question of symmetry between open economy and open society}

The article discusses the problem of absence of symmetry between opening of the economy and opening of the society. Even though both discussed occurrences have their history, they are studied separately. In the article a hypothesis is put on existence of asymmetry between opening of the economy and opening of the society and this fact is seen as one of the obstacles which limits both studied and analysed processes. The attention in the article is turned to fact that there are measures which help to estimate the scale of opening of an economy, however there are no similar tools to measure openness of a society. This asymmetry limits our ability to understand the problem and to construct tools necessary to reduce it. The aim of the article is not to show actions or a plan for narrowing the existing 
gap between the two processes but pointing at the role of those two processes in shaping the effective policy in the two fields.

Keywords: open economy, open society, measurement of openness, methods of opening, symmetry and asymmetry of opening

\section{Literatura}

1. Amerykańskie wybory prezydenckie w erze postprawdy. Aktorzy, strategie, konteksty, red. J. Misiuna, M. Molęda-Zdziech, S. Łubiarz, OficynaWydawnicza SGH, Warszawa 2018.

2. Amish Population Profile, Elizabethtown College, „The Young Center for Anabaptist and Pietist Studies" 2017.

3. As GM Falters, Opel Seeks Government Help, 17.11.2008, Spiegel Online, http://www. spiegel.de/international/germany/auto-industry-bailout-as-gm-falters-opel-seeks-government-help-a-590906.html

4. Atkinson R.D., Ezeell S.J., Innovation Economics. The Race for Global Advantage, Yale University Press, New Haven-London 2012.

5. Attitudes towards Immigration and their Antecents: Topline Results from Round 7 of the European Social Survey, November 2016; In depth Gallup Survey on Religion, Gallup USA 2017.

6. Bergson H., The Two Sources of Morality and Religion (tłum. $\mathrm{z}$ franc. R. Ashley Andra, C. Brereton), Doubleday Anchor 1935; tytuł oryg. Les deux sources de la morale et de la religion, 1932.

7. Cares S., Garnero A., Martin S., The State of Trade Unions, Employer Organizations and Collective Bargaining in OECD Countries, OECD, Paris 2017.

8. Dornbush K., Fisher S., Starz R., Macroeconomics, McGraw-Hill Book Comp. 2001, $8^{\text {ht }}$ ed., (DFS), http://highered.mcgraw-hill.com/sites/0072823402/information_ center_view0/

9. Gellately R., Lenin, Stalin, Hitler: The Age of Social Catastrophe, Vintage, London 2008.

10. Human Development Report 2016, UN, New York 2016.

11. Keohane R.O., Nye J.S., Power and Interdependence, Pearson Education, New York 2001.

12. Krugman P., Wells R., Macroeconomics, $4^{\text {th }}$ ed., Worth Publ., New York 2015.

13. Mankiw N.G., Macroeconomics, $4^{\text {th }}$ ed., 1999, http://bcs.worthpublishers.com/mankiw6/

14. Mortensen Ch.E., The Leibnitz Continuity Condition, Inconsistency and Quantum Dynamics, 1997, Oai:digital.library.adelaide.edu.au:2440/1607

15. Nash J.C., Fernandez-Kelly M.P., Women, Men, and the International Division of Labor, Sunny Press, New York 1983. 
16. O’Brien R., Williams M., Global Political Economy, $3^{\text {rd }}$ ed., Palgrave-Macmillan, London 2010.

17. Ozimek A., Reinventing Unions for $21^{\text {st }}$ century, „Forbes” 29.10.2012.

18. Popper K.R., The Open Society and its Enemies, Routledge, London 1995.

19. Priest G., Paradoxical Truth, „The New York Times” 28.11.2010, https://opinionator. blogs.nytimes.com/2010/11/28/paradoxical-truth/

20. Raworth K., Doughnut Economics. 7 ways to think like a 21st Century Economist, Chelsea Green Publ., Vermont 2017.

21. Topline Results from Round 7 of the European Social Survey, November 2016; In depth Gallup Survey on Religion, Gallup USA 2017.

22. Trade Unions and the global crisis. Labour's visions, strategies and responses, red. M. Serrano, E. Xhafa, M. Fichter, International Labour Office, Geneva 2011.

23. Transformacja systemowa w Polsce, red. K. Żukrowska, Oficyna Wydawnicza SGH, Warszawa 2010.

24. US Exempts Some Allies From Tariffs but May Opt for Quotas, „The New York Times” 22.03.2018.

25. Vos R., Ganuza E., Morley S., Robinson Sh., Who Gains from Free Trade. Export-led growth, inequality and poverty in Latin America, Routledge Studies in Development Economics, London-New York 2006.

26. Żukrowska K., Ocena interesów gospodarczych i politycznych w układzie Świat Zachodni - Azja, [w:] Kryzysy systemowe. Zagrożenia globalne barierami rozwoju, red. nauk. E. Mączyńska, J.J. Michalak, J. Niżnik, Polska Akademia Nauk, Komitet Prognoz Polska 2000+, Warszawa 2013.

27. Żukrowska K., Powiązania liberalizacyjne rynków z różnych regionów/Liberalizationties of markets from different region, "Ekonomia XXI wieku/Economics of the $21^{\text {st }}$ Century" UE we Wrocławiu 3(11), 2016, s. 11-25.

28. Żukrowska K., Rozwój Unii Europejskiej do 2020 roku a nowe wyzwania globalizacji i konkurencji międzynarodowej z uwzględnieniem roli, miejsca i interesów Polski, „Krakowskie Studia Międzynarodowe” nr 1 (XVII), 2017, s. 17-34.

29. Żukrowska K., Rynek USA: pierwsze reakcje na wynik wyborów prezydenckich i realizacja haseł gospodarczych z kampanii wyborczej, [w:] Amerykańskie wybory prezydenckie w erze postprawdy. Aktorzy, strategie, konteksty, red. J. Misiuna, M. Molęda-Zdziech, S. Łubiarz, Oficyna Wydawnicza SGH, Warszawa 2018.

30. https://eeas.europa.eu/headquarters/headquarters-homepage/area/geo_en

31. http://www.heritage.org/index/country/poland

32. http://www.heritage.org/index/ranking

33. https://www.imf.org/external/np/sec/memdir/memdate.htm

34. http://www.worldbank.org/en/about/leadership/members 
35. https://www.wto.org/english/thewto_e/whatis_e/tif_e/org6_e.htm

36. https://www.wto.org/english/thewto_e/whatis_e/tif_e/org6_e.htm\#observer 